\title{
A Comparison of the Recognition of Overwork- related Cardiovascular Disease in Japan, Korea, and Taiwan
}

\author{
Jungsun PARK ${ }^{1}$, Yangho KIM²*, Yawen CHENG $^{3}$ and Seichi HORIE ${ }^{4}$ \\ ${ }^{1}$ Korea Occupational Safety and Health Agency, Incheon, South Korea \\ ${ }^{2}$ University of Ulsan College of Medicine, \#290-3 Cheonha-Dong, Dong-Gu, Ulsan 682-060, South Korea \\ ${ }^{3}$ National Taiwan University, Taipei, Taiwan \\ ${ }^{4}$ University of Occupational and Environmental Health, Kitakyushu, Japan
}

Received August 17, 2011 and accepted November 2, 2011

Published online in J-STAGE December 6, 2011

\begin{abstract}
In Japan, Korea, and Taiwan, cerebrovascular and cardiovascular diseases (CVDs) caused by overwork are recognized by government as work-related. These three countries are the only countries in the world that officially recognize CVDs caused by psychosocial factors (e.g., overwork) as work-related cerebrovascular and cardiovascular diseases (WR-CVDs), and compensate employees accordingly. The present study compared the similarities and differences among the recognition of overwork-related CVDs in Japan, Korea, and Taiwan. The criteria by which WR-CVDs are identified are very similar in the three countries. However, in the interval surveyed (1996-2009), Korea had a remarkably larger number of recognized WR-CVD patients than did Japan or Taiwan. Recognition of occupational diseases is influenced by various factors, including socio-cultural values, the nature of occupational health care schemes, the extent of the social security umbrella, national health insurance policy, and scientific evidence. Our results show that social factors may be very different among the three countries studied, although the recognition criteria for WR-CVDs are quite similar.
\end{abstract}

Key words: Overwork, Work-related cerebrovascular and cardiovascular diseases (WR-CVDs), Recognition

\section{Introduction}

Many European countries and the USA consider that cerebrovascular and cardiovascular diseases (CVDs) developing in workers are public health rather than occupational health issues ${ }^{1)}$. However, Japan, Korea, and Taiwan consider CVDs in workers to be work-related CVDs (WR-CVDs), and that such diseases are very important occupational health issues. CVDs can be caused by over-

*To whom correspondence should be addressed.

E-mail: yanghokm@nuri.net

(C)2012 National Institute of Occupational Safety and Health work alone; additionally, however, underlying conditions (hypertension, atherosclerosis, and diabetes mellitus) in those who suffer from WR-CVDs are recognized as being significantly aggravated by overwork, especially by accumulation of fatigue caused by long working hours ${ }^{2}$.

Japan, Korea, and Taiwan are the only countries in the world to recognize CVDs caused by psychosocial factors (e.g., overwork) as WR-CVDs and to compensate employees accordingly ${ }^{3)}$. The present study was performed to compare the similarities and differences among the recognition of WR-CVDs in Japan, Korea, and Taiwan. 


\section{Method}

Occupational health professionals from South Korea, Japan, and Taiwan compared the recognition criteria for WR-CVDs in the three countries, and analyzed the differences and the similarities between socio-cultural schemes affecting workers' compensation for CVDs. The professionals also analyzed the nature of general health care schemes, worker socioeconomic status, the prevalence of labor unions, the social influences exerted by labor and management, and work culture.

\section{Results}

\section{The recognition criteria for $W R-C V D s$}

As the historical base of the occupational safety and health laws in these three countries arises from the Industrial Safety and Health Law of Japan promulgated in 1972, the basic framework of the recognition criteria for WRCVDs in the three countries are very similar (Table 1$)^{4-6)}$. Psychosocial factors associated with overwork may be classified into three types in all three countries. The first type of psychosocial factor is an unusual episode such as extreme surprise or fear, unusually heavy physical exertion, and/or an episode of violent anger, occurring within $24 \mathrm{~h}$ prior to the onset of the disease. The second type of psychosocial factor is excessive overwork over a relatively short period (1 wk or so) which may cause physiological collapse. The third type of psychosocial factor is chronic overwork; this means, for example, "100 h overtime in the last month" or a "monthly average of 80 h overtime during the last 2-6 months".

\section{The numbers of WR-CVDs recognized annually}

Figure 1 shows that social factors may differ markedly among the three countries although the recognition criteria for WR-CVDs are quite similar ${ }^{7-9}$. Korea had remarkably greater numbers of recognized WR-CVDs during the entire interval studied (1996-2009), compared to those of Japan or Taiwan. Such numbers increased rapidly in the interval since 1999, peaked in 2003, and have decreased in the time since 2005. Japan has shown a gradually increasing number of recognized WR-CVDs in the interval since 2002. The numbers are greater than are those of Taiwan, but much smaller than those of Korea. In Taiwan, WRCVDs began to be recognized in 2006, but the annual number remains under 50 , thus smaller than the numbers for Japan.
Comparison of socio-cultural schemes affecting recognition of WR-CVDs

Table 2 compares the differences and similarities among socio-cultural schemes affecting recognition of WR-CVDs in South Korea, Japan, and Taiwan. Relevant factors include the existence and nature of general health care schemes, worker socioeconomic status, the extent of labor unionization, social perceptions of labor and management, and working culture. Several political, economic, or cultural factors that might affect the numbers of recognized WR-CVDs in the three countries are discussed below.

First, the numbers of workers covered by workers' compensation schemes in Japan, Korea, and Taiwan were $52,788,681,14,200,000$, and 8,795,000, respectively, in $2010^{13-15)}$. Thus, the number of such workers in Japan was 3.7-fold that of Korea, and the number in Taiwan 0.6-fold that of Korea. However, the age-standardized death rates from cerebrovascular disease per 100,000 subjects in the general populations of Korea (2006), Japan (2008), and Taiwan (2009), were 77.0, 42.7, and 32.8, respectively ${ }^{27)}$. The age-standardized death rates from cardiovascular disease per 100,000 subjects in Korea (2006), Japan (2008), and Taiwan (2009), were 35.9, 27.4, and 47.7, respectively $^{27)}$.

Second, Japanese general health care schemes provide sick-leave benefits amounting to $2 / 3$ of salary for up to 18 months to workers suffering from disease not related to work, whereas Korea and Taiwan do not ${ }^{17)}$.

Third, labor unions have a stronger influence on Korean society than is the case in Japan or Taiwan; this is especially true of large enterprises in Korea.

Fourth, the recognition criteria for WR-CVDs in Korea are not as detailed as are those of Japan or Taiwan ${ }^{4-6)}$. In addition, prior to legal amendment in July 2008, almost all cerebrovascular hemorrhages occurring during work had been readily compensated, irrespective of the extent of work-relatedness ${ }^{2}$.

\section{Discussion}

The recognition criteria for WR-CVDs are very similar in Korea, Japan, and Taiwan, especially in the latter two countries.

The basic psychosocial factor recognized is overwork. The term "karoshi" was first used by Uehata in a presentation on 17 fatalities caused by excessive overwork, given at the 51st Annual Conference of the Japan Society of Occupational Health in $1978^{28)}$. In the early 1970 s, before the term had been coined, expressions such as "sudden death" 


\section{Table 1. Comparison of recognition criteria for WR-CVDs in Korea, Japan, and Taiwan}

Korea

(Amendment of July 2008)

A. If a worker suffers from any of intracerebral hemorrhage, subarachnoid hemorrhage, cerebral infarction, myocardial infarction, or a dissecting aneurysm of the aorta, caused by any of the conditions listed below, that disease is treated as a compensable work-related disease. Conditions that result from natural pathological processes will not be considered to be work-related.

1) Situations that cause significant physiological changes in workers who have experienced unexpected accidental strain, agitation, fear, shock, or a dramatic change in the work environment just prior to the onset of disease.

2) Situations that cause mental and physical exhaustion as a result of increased workload, working hours, work intensity, job responsibility, or a change in the work environment occurring a brief period before the onset of disease.

3) Situations that cause mental and physical overload caused by chronic overwork following a change in workload, working hours, work intensity, job responsibility, or the work environment.

B. A condition can also be considered work-related if any cerebrovascular or cardiovascular disease not mentioned above is triggered or aggravated in a chronological and medical manner.

C. Instructions necessary for evaluation of the work-related nature of conditions described in A and B above shall be prepared via Notification by the Minister of MOEL.

(Remark: Prior to amendment of the criteria in July 2008, all cerebrovascular hemorrhages occurring during work had been recognized as work-related diseases).

Japan

(Amendment of Dec. 2001) $)^{5}$
If a worker suffers from intracerebral hemorrhage, subarachnoid hemorrhage, cerebral infarction, hypertensive encephalopathy, myocardial infarction, angina pectoris, cardiac arrest (including sudden cardiac death), or a dissecting aneurysm of the aorta has experienced an "obviously excessive burden of work", as defined in (1), (2), or (3) below, that worker is considered to have a compensable occupational disease (that is, a disease equivalent to a disease of category 8 of Table 1-2 of the "Enforcement Regulations of Labor Standards Law").

(1) Abnormal event; An abnormal event includes i) extreme tension, excitement, fear, or wonder or, ii) an accidental or unpredictable incident, which urgently presses a worker under a physical burden; or, iii) a rapid and significant change in the working environment.

The time and location of the occurrence must be clear. The incident must occur just before appearance of a disease, or on the previous day.

(2) Short-term excessive heavy work: A worker has taken on a clearly excessive workload which imposes a very significant physical or mental burden (compared with that of normal work) within approximately 1 week prior to the appearance of a disease.

(3) Long-term excessive heavy work: A worker has engaged in long-term excessive heavy work. A stronger correlation can be assumed between a worker's work and the appearance of a disease, if a worker has experienced working of overtime hours in excess of about 100 hours during the 1 month prior to the appearance of disease, or by the working of overtime in excess of about 80 hours per month during a time period of 2 to 6 months prior to the appearance of such disease.

Factors other than working hours that contribute to an excessive work burden should also be adequately considered. These include an irregular work pattern, the need for frequent business trips, shift and late-night work, work with long compulsory attendance hours, the working environment (in terms of temperature, noise level, and any time difference compared with time in the home country), and work that is mentally stressful.

The types of illnesses that can be attributed to overwork, according to the Council's definition, include the following: (1) cerebrovascular diseases (cerebral hemorrhage, cerebral infarction, subarachnoid hemorrhage, and brain damage caused by severe hypertension); (2) heart diseases (myocardial infarction, acute heart failure, dissecting aneurysm of the aorta, angina pectoris, serious cardiac arrhythmia, cardiac arrest, and sudden cardiac death).

The recognition of a disease as being caused by overwork requires the presence of one of the following features: (1) an unusual event that triggers extreme psychological tension, excitement, fear, stress, the taking on of an extreme physical workload, or a dramatic change in work environment; (2) short-term overwork, defined as the existence of an irregular work schedule, working for long hours, engaging in frequent travel, performance of shift work, or exposure to extreme temperature or noise (for example) during the week prior to the event; (3) long-term overwork, defined as the working of 92 or more overtime hours during the month prior to the event, or working an average of 72 hours overtime per month during the 2nd to 6th months prior to the event.

Diseases that are not mentioned above, or diseases that are mentioned above but to which work-unrelated factors contribute more than $50 \%$ of the risk of development of such a disease, will not be considered to be work-related. 


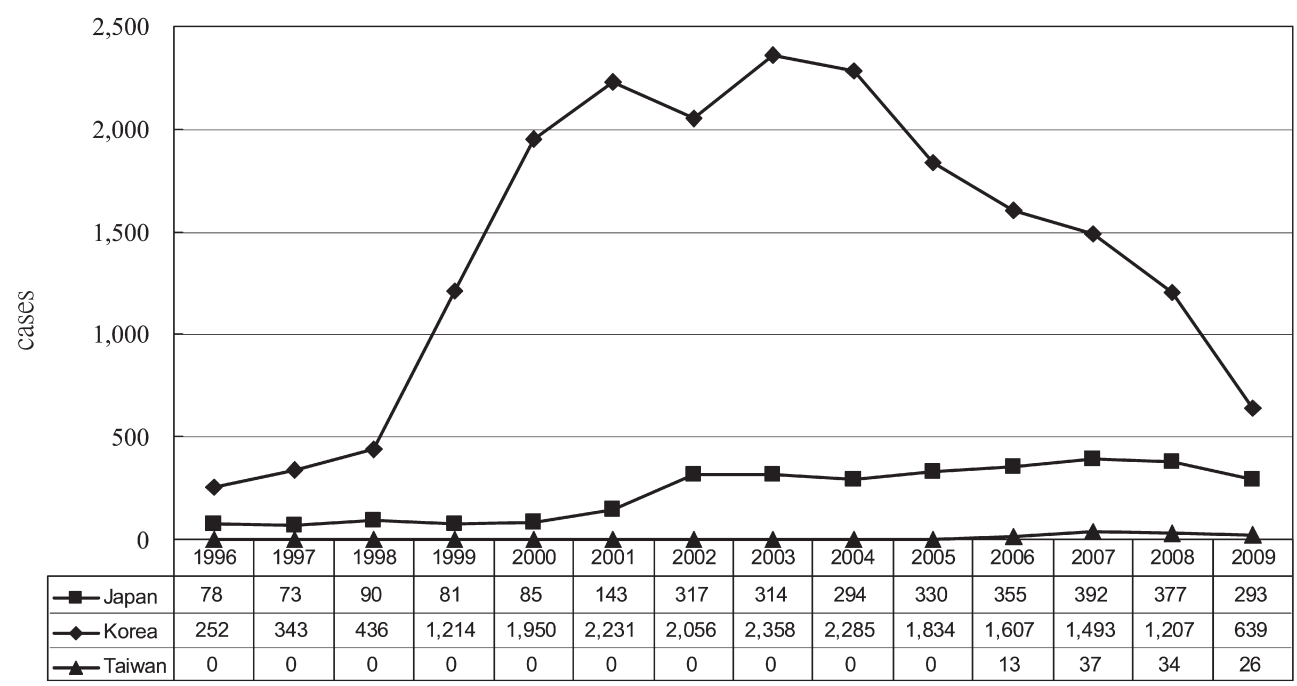

Fig. 1. Numbers of recognized work-related CVD cases in Japan, Korea, and Taiwan: 1996-2009 ${ }^{7-9)}$.

or "dying at one's post of duty" were used. Such workrelated cardiovascular disease induced by psychosocial factors is unique.

The types of overwork involved are as follows ${ }^{3)}$.

The first type of psychosocial factor includes triggers of acute injury rather than causative factors of chronic disease. The clinical evidence suggests that the natural history of coronary artery disease is punctuated by clinical manifestations of acute coronary syndrome triggered (for example) by heavy physical exertion ${ }^{29,30)}$ or episodes of anger ${ }^{31}$. Therefore, this type of cardiovascular disease may also be considered to be work-related in European countries and the USA. The second type of psychosocial factor is associated with extreme work situations during short period (for example) by successive overnight work to meet a deadline. The third set of factors involves excessive overwork that may be socially acceptable, or indeed coerced, in specific socio-cultural situations such as in Japan, Korea, or Taiwan. Under such conditions, the chronic work overburden makes it clearly impossible to take the minimum sleep time (i.e., 4-6 h) needed to recover from fatigue, and leads to development of WR-CVD ${ }^{5}$.

The fact that the numbers of WR-CVD patients recognized annually are very different among the three countries despite the existence of very similar disease criteria suggests that differences in socio-economic or cultural values affect the recognition of WR-CVDs. Recognition of occupational diseases tends to be influenced by various factors, including socio-cultural values, the nature and extent of occupational health care schemes, social security rules, general health insurance scheme, and medical evidence of the work-relatedness of disease.

When a Korean worker suffers from a disease, it is very important that he or she should seek workers' compensation, because no alternative such as a sick leave benefit offered by a general health care scheme is available; the situation is otherwise in Japan. Therefore, more ill workers claim workers' compensation in Korea than in Japan or Taiwan. Especially, prior to amendment of the law in July 2008, almost all cerebrovascular hemorrhages occurring at work were readily compensated, irrespective of the degree of work-relatedness ${ }^{32,33)}$. In addition, the mortality rate from CVDs in the general Korean population is much higher than that in Japan. Thus, the number of recognized WR-CVD patients in Korea is much greater than in Japan, although the number of workers covered by workers' compensation schemes in Korea is less than one-third that in Japan. In Taiwan, the number of workers allegedly dying from overwork is growing, and the Council of Labor Affairs of Taiwan has been accused of not adequately protecting workers against overwork hazards. In response to such social concerns, the Council has loosened the relevant criteria, to render it easier for doctors and investigators to qualify a case as work-related death or injury from overwork. This seems the same dialog as in Japan; the governmental notice of judging work-relatedness has experienced major amendment twice in 1987 and in 2001, both following the decision made by Supreme Court of Japan ${ }^{6}$.

However, the number of recognized WR-CVD patients in Korea has continuously decreased since the peak was attained in 2003. Several explanations may be advanced. 
Table 2. Socio-cultural factors affecting the award of workers' compensation to those suffering from WR-CVDs, and details of the compensation processes in Korea, Japan, and Taiwan

\begin{tabular}{|c|c|c|c|}
\hline & Korea & Japan & Taiwan \\
\hline $\begin{array}{l}\text { Coverage by general health care } \\
\text { schemes. }\end{array}$ & All subjects ${ }^{11)}$ & All subjects ${ }^{10)}$ & All subjects ${ }^{12)}$ \\
\hline $\begin{array}{l}\text { No. of workers covered by } \\
\text { workers' compensation schemes. }\end{array}$ & $14,200,000(2010)^{14)}$ & $52,788,681\left(\right.$ March, 2010) ${ }^{13)}$ & $9,397,608(2010)^{15)}$ \\
\hline $\begin{array}{l}\text { The proportion of medical } \\
\text { costs paid by patients as either } \\
\text { outpatients or inpatients }(\%) \text {. }\end{array}$ & $\begin{array}{l}\text { Outpatients: } 50 \% \\
\text { Inpatients: } 40 \%{ }^{16)}\end{array}$ & $\begin{array}{l}\text { Outpatients: } 30 \% . \\
\text { Inpatients: } 30 \% . \\
\text { Patients } 75+\text { years of age and } \\
\text { annual taxable income of less than } \\
1.45 \text { million yen: } 10 \%{ }^{10)}\end{array}$ & $\begin{array}{l}\text { Outpatients: } \sim 20 \% \text {. } \\
\text { Inpatients: } \sim 10 \% \text {. } \\
\text { Co-payments are waived for } \\
\text { the very poor, war veterans, and } \\
\text { aborigines }^{12)}\end{array}$ \\
\hline $\begin{array}{l}\text { Sick-leave benefits given by } \\
\text { general health care schemes. }\end{array}$ & - & $\begin{array}{l}+ \\
2 / 3 \times \text { average income in the most } \\
\text { recent } 3 \text { months }^{10)}\end{array}$ & - \\
\hline $\begin{array}{l}\text { Normal weekly working hours } \\
\text { dictated by Labor Standard } \\
\text { Laws. }\end{array}$ & $40^{18)}$ & $40^{19)}$ & $42^{15)}$ \\
\hline Yearly mean work hours. & $2,193 \mathrm{~h}(2010)^{20)}$ & $\begin{array}{l}1,798 \mathrm{~h}(2010) \\
\text { this is the average from workplaces } \\
\text { with } 30+\text { employees }^{21)}\end{array}$ & $2,074 \mathrm{~h}(2010)^{15)}$ \\
\hline $\begin{array}{l}\text { Proportions of workers in labor } \\
\text { unions. }\end{array}$ & $\begin{array}{l}(2009): \\
\text { By worksite: } 10.1 \%{ }^{22)}\end{array}$ & $\begin{array}{l}(2010) \text { : } \\
\text { By worksite: } 18.5 \%{ }^{23)}\end{array}$ & $\begin{array}{l}\text { (2010): } \\
\text { By worksite: } 3.3 \%{ }^{15)} \\
\text { All workers: } 15.4 \%\end{array}$ \\
\hline The social influence of labor. & Strong & Moderate & Weak \\
\hline $\begin{array}{l}\text { Tripartite organization, } \\
\text { including government, labor, } \\
\text { and management. }\end{array}$ & + & + & - \\
\hline $\begin{array}{l}\text { Organization determining the } \\
\text { work-relatedness of disease } \\
\text { when award of workers' } \\
\text { compensation is considered. }\end{array}$ & $\begin{array}{l}\text { Adjudication Committee consisting } \\
\text { of members of various backgrounds } \\
(2008.7)^{24)}\end{array}$ & $\begin{array}{l}\text { Labor Standard Office, with } \\
\text { comments from consulting medical } \\
\text { doctors on the extent of work- } \\
\text { relatedness of the illness }^{25)}\end{array}$ & $\begin{array}{l}\text { Adjudicating committee of the } \\
\text { Council of Labor Affairs, consisting } \\
\text { of 5-10 occupational physicians, } 1-2 \\
\text { industrial hygienists, } 1 \text { legal expert } \\
\text { and } 3 \text { governmental officials }\end{array}$ \\
\hline $\begin{array}{l}\text { Existence of detailed guidelines } \\
\text { for determination of disease } \\
\text { work-relatedness. }\end{array}$ & $\begin{array}{l}\text { Less quantitative } \\
\text { Less detailed }\end{array}$ & Detailed guidelines & $\begin{array}{l}\text { Detailed guidelines including both } \\
\text { quantitative and qualitative criteria }\end{array}$ \\
\hline $\begin{array}{l}\text { Age-standardized death rate of } \\
\text { cerebrovascular disease using } \\
\text { standard OECD population in } \\
1990^{27} \text {. }\end{array}$ & $\begin{array}{l}\text { Total: } 77.0 \\
\text { Male: } 96.8 \\
\text { Female: } 64.0 \\
\text { per 100,000 subjects (2006) } \\
\end{array}$ & $\begin{array}{l}\text { Total: } 42.7 \\
\text { Male: } 56.1 \\
\text { Female: } 32.3 \\
\text { per 100,000 subjects (2008) }\end{array}$ & $\begin{array}{l}\text { Total: } 32.8 \\
\text { Male: } 41.2 \\
\text { Female: } 27.0 \\
\text { per } 100,000 \text { subjects (2009) }\end{array}$ \\
\hline $\begin{array}{l}\text { Age-standardized death rate of } \\
\text { cardiovascular disease using } \\
\text { standard OECD population in } \\
1990^{27)} \text {. }\end{array}$ & $\begin{array}{l}\text { Total: } 35.9 \\
\text { Male: } 46.5 \\
\text { Female: } 28.2 \\
\text { per } 100,000 \text { subjects (2006) } \\
\end{array}$ & $\begin{array}{l}\text { Total: } 27.4 \\
\text { Male: } 39.6 \\
\text { Female: } 17.7 \\
\text { per 100,000 subjects (2008) }\end{array}$ & $\begin{array}{l}\text { Total: } 47.7 \\
\text { Male: } 59.9 \\
\text { Female: } 38.8 \\
\text { per 100,000 subjects (2009) }\end{array}$ \\
\hline $\begin{array}{l}\text { Compensation criteria for WR- } \\
\text { CVDs in terms of relationships } \\
\text { between triggering factors and } \\
\text { pre-existing cardiovascular } \\
\text { diseases. }\end{array}$ & $\begin{array}{l}\text { Compensation is probable if } \\
\text { occupational triggering factors } \\
\text { are confirmed irrespective of } \\
\text { the existence of a pre-existing } \\
\text { cardiovascular disease }^{4)}\end{array}$ & $\begin{array}{l}\text { Compensation is probable if oc- } \\
\text { cupational factors are confirmed } \\
\text { to be a significant cause of the } \\
\text { cardiovascular disease, based on the } \\
\text { guidelines }\end{array}$ & $\begin{array}{l}\text { Compensation is probable if the } \\
\text { proportion of occupational factors } \\
\text { contributing to development of WR- } \\
\text { CVD is over } 50 \%{ }^{6}\end{array}$ \\
\hline
\end{tabular}


First, Korean governments have launched preventive measures directed against WR-CVDs, commencing in the early 2000s. Intensive and comprehensive risk assessment and management of WR-CVDs among high-risk workers with several risk factors including hypertension, dyslipidemia, diabetes, and smoking status, via the implementation of general health examination schemes, may have prevented triggering of WR-CVDs. Such preventive strategies are based on the understanding that most WRCVDs are in reality conditions that have been complicated by progression of underlying diseases such as hypertension or atherosclerosis ${ }^{3)}$. Thus, intensive management of both the underlying diseases, and aggravating factors such as overwork, are essential to prevent WR-CVDs ${ }^{34,35)}$. Second, prior regulations by which almost all cerebrovascular hemorrhages occurring in subjects who were at work had been readily recognized as deserving of compensation, irrespective of the extent of work-relatedness, were amended in July 2008, and recognition of WR-CVDs has thus been affected.

\section{References}

1) Korea Occupational Safety and Health Agency (2009) National Profiles of Occupational Safety and Health System in Some Developed Countries with a Focus on WorkRelated Musculoskeletal and Cardiovascular Diseases, and Mental Health-Related Ill Health. KOSHA, Seoul.

2) Park J, Kim Y, Hisanaga N (2011) Work-related cerebrovascular and cardiovascular diseases (WR-CVDs) in Korea. Ind Health 49, 3-7.

3) Park J (2006) Impact of Acute Coronary Syndrome (ACS) on Work-relatedness evaluation in cerebrovascular and cardiovascular diseases among workers. J Occup Health 48, $141-4$.

4) Ministry of Employment and Labor (2008) The Recognition Criteria for Work-related cerebrovascular and cardiovascular diseases (The Enforcement decree of the industrial Accident Compensation Insurance Act). http:// www.law.go.kr/LSW/1sSc.do?menuId=0\&p1=\&subMenu= $1 \&$ searchName $=$ LicLs $\% 2$ C0\&query $=\% \mathrm{EC} \% 82 \% \mathrm{~B} 0 \% \mathrm{EC}$ $\% 97 \% 85 \% \mathrm{EC} \% 9 \mathrm{E} \% \mathrm{AC} \% \mathrm{ED} \% 95 \% \mathrm{~B} 4 \% \mathrm{~EB} \% \mathrm{~B} 3 \% \mathrm{~B} 4 \% \mathrm{E}$ C\%83\%81\%EB\%B3\%B4\%ED\%97\%98\%EB\%B2\%95\&x $=17 \& y=10$ \#AJAX. Accessed August 17, 2011(in Korean).

5) Labor Standards Bureau, Ministry of Health, Labour and Welfare (2001) Recognition standards for cerebro-vascular diseases, ischemic heart diseases, etc. (excluding those attributable to injuries), Notice No. 1063 of the Labor Standards Bureau. http://www.mhlw.go.jp/houdou/0112/ h1212-1.html. Accessed August 19, 2011 (in Japanese).

6) Council of Labor Affairs, Executive Yuan, Taiwan. Guideline for the recognition of work induced cerebrovascular and cardiovascular diseases (excluding diseases caused by external traumatic factors), promulgated on 12/17/2011 (Chinese version available at: http://www. cla.gov.tw/cgi-bin/siteMaker/SM_themePro?page $=4 \mathrm{~cd} 0 \mathrm{cc} 3$ 8\&status=audit; Accessed August 17, 2011.

7) Korean Occupational Safety Health Agency (KOSHA). Statistics on Industrial Accident. http://www.kosha.or.kr/ bridge?menuId=553. Accessed August 19, 2011.

8) Council of Labor Affairs, Executive Yuan, Taiwan. http:// statdb.cla.gov.tw/statis/stmain.jsp?sys $=100$. Accessed August 19, 2011.

9) Compensation Division, Workers' Compensation Administration Division, Worker's Compensation Department, Labour Standards Bureau, Ministry of Health, Labour and Welfare. http://www.mhlw.go.jp/ houdou/2002/05/h0522-2.html, http://www.mhlw.go.jp/ houdou/2006/05/h0531-1.html, http://www.mhlw.go.jp/stf/ houdou/2r98520000006kgm.html. Accessed August 19, 2011.

10) Health Insurance System in Japan. http://www.mhlw.go.jp/ bunya/iryouhoken/iryouhoken01/01.html. Accessed August 19,2011

11) Ministry of Health and Welfare. Health Insurance. http:// english.mw.go.kr/front_eng/jc/sjc0108mn.jsp?PAR MENU_ID=100314\&MENU_ID $=10031401$. Accessed August 19, 2011.

12) Department of Health. http://www.doh.gov.tw/. Accessed August 19, 2011.

13) Workers' Compensation Insurance Monthly Report. http:// www.mhlw.go.jp/toukei/list/136-1.html. Accessed August 19, 2011.

14) Korean Occupational Safety Health Agency (KOSHA). Statistics. http://english.kosha.or.kr/main. Accessed August 19,2011

15) Council of Labor Affairs, Executive Yuan, Taiwan. http:// statdb.cla.gov.tw/statis/. Accessed August 19, 2011.

16) Ministry of Health and Welfare. Health Insurance. http:// english.mw.go.kr/front_eng/jc/sjc0108mn.jsp?PAR MENU_ID=100314\&MENU_ID $=10031406$. Accessed August 19, 2011.

17) Accident and Sickness Benefits of Health Insurance. http:// www.sia.go.jp/seido/iryo/kyufu/kyufu07.htm. Accessed August 19, 2011.

18) Ministry of Employment and Labor. Labor Standards. http:// www.moel.go.kr/english/topic/laborlaw.jsp?tab=Standards. Accessed August 19, 2011.

19) Ministry of Employment and Labor. Labour Standard Law (Japan) Article 32.

20) Organization for Economic Cooperation and Development (OECD). OECD. StatExtracts. http://stats.oecd.org/Index. aspx?DatasetCode=ANHRS. Accessed August 19, 2011.

21) Monthly Statistical Survey on Labour. http://www.mhlw. go.jp/toukei/itiran/roudou/monthly/22/22r/mk22r.html. Accessed August 19, 2011.

22) Ministry of Employment and Labor. Labor Standards. 
http://www.index.go.kr/egams/stts/jsp/potal/stts/PO_STTS_ IdxMain.jsp?idx_cd=1511. Accessed August 19, 2011.

23) Result of Basic Survey on Trade Union in 2009. http:// www.mhlw.go.jp/toukei/itiran/roudou/roushi/kiso/09/index. html. Accessed August 19, 2011.

24) Ministry of Employment and Labor (2008) The industrial Accident Compensation Insurance Act.

25) Rousaihoken Information Center. http://www.rousai-ric. or.jp/. Accessed August 19, 2011.

26) Regulation for the committee for the adjudication of occupational disease (last amended on December 8th, 1999), Council of Labor Affairs, Executive Yuan, Taiwan. http://laws.cla.gov.tw/Chi/FLAW/FLAWDAT0202.asp. Accessed August 19, 2011.

27) Ministry of Health and Welfare and Korea Institute for Health and Social Affairs. OECD Health Data 2010. 2011 (in Korean).

28) Haratani T, Karoshi (1998) Death from overwork. In: Encyclopedia of Occupational Health and Safety. 4th Ed., Stellman JM (Ed.), 5.18-5.19, International Labour Office, Geneva.

29) Mittleman MA, Maclure M, Tofler GH, Sherwood JB, Goldberg RJ, Muller JE (1993) Triggering of acute myocardial infarction by heavy physical exertion. Protection against triggering by regular exertion. Determinants of Myocardial Infarction Onset Study Investigators. N Eng J Med 329, 1677-83.
30) Willich SN, Lewis M, Lowel, Arntz HR, Schubert F, Schröder R (1993) Physical exertion as a trigger of acute myocardial infarction. Triggers and Mechanism of Myocardial Infarction Study Group. N Engl J Med 329, 1684-90.

31) Futterman LG, Lemberg L (2002) Anger and acute coronary events. Am J Crit Care 11, 574-6.

32) Park J (2005) Why the decision on work-related cerebrovascular and cardiovascular diseases (WR-CVDs) is unable to guarantee fairness and promptitude? Korean $\mathrm{J}$ Occup Health 44, 103-12.

33) Won J-K, Ha KW, Song JS, Roh J, Kim HR, Le DH, Lee KH (2003) Analysis of sufficient conditions in approving cerebrovascular and cardiovascular disease as occupational disease. Korean J Occup Environ Med 15, 52-60 (in Korean).

34) Assmann G, Carmena R, Culle P, Fruchart JC, Jossa F, Lewis B, Mancini M, Paoletti R (1999) Coronary healrt disease: reducing the risk $-\mathrm{A}$ worldwide view. Circulation 100, 1930-8.

35) Grundy SM, Balady GJ, Criqui MH, Fletcher G, Greenland P, Hiratzka LF, Miller NH, Etherton KP, Krumholz HM, LaRosa J, Ockene IS, Pearson T, Reed J, Washington R (1998) Primary prevention of coronary heart disease: guidance from framingham. A statement for healthcare professionals from the AHA task force on risk riduction. Circulation 97, 1876-87. 